\title{
Original Research \\ Qualitative interviews of pharmacy interns: determining curricular preparedness for work life
}

\section{leva STUPANS}

Received (first version): 19-Oct-2011

Accepted: 16-Feb-2012

\author{
ENTREVISTAS CUALITATIVAS DE \\ INTERNOS DE FARMACIA: \\ DETERMINANDO LA PREPARACIÓN \\ CURRICULAR PARA LA VIDA LABORAL
}

\section{RESUMEN}

Uno de los puntos claves que afectan a la transición entre la universidad al empleo remunerado es la percepción del graduado sobre su capacidad de realizar satisfactoriamente el trabajo de un graduado. En algunas profesiones como enfermería, se refieren al concepto de "shock de transición". Se necesita entender como perciben los estudiantes de farmacia su transición a su primer trabajo como farmacéuticos internos e identificar los posibles huecos en el currículo de farmacia. Hasta la fecha, se ha publicado poca evidencia sobre si los programas universitarios son efectivos para equipar a los graduados en farmacia para transitar al mundo laboral.

Objetivos: Explorar desde la perspectiva de los nuevos profesionales farmacéuticos, graduados de una de las Universidades australianas, las áreas que necesitan ser trabajadas en los programas que preparan graduados para la transición al mundo laboral como internos en farmacia.

Métodos: Análisis temático de entrevistas con internos.

Resultados: Se identificaron subtemas en las respuestas - relaciones con el lugar de trabajo y necesidad de los graduados de interesarse pro otra gente, ajustarse a las horas de trabajo, y la diferencia entre los exámenes de la universidad y la actuación en el ligar de trabajo. Los graduados hicieron como sugerencias que se aumentase el periodo de estancia en el programa de farmacia. Conclusiones: Los graduados en farmacia parecen estar preparados para el mundo laboral farmacéutico. El concepto de "shock de transición" o "estrés de transición", descritos para otros profesionales de la salud, no fue aparente.

Palabras clave: Competencia Clínica. Educación en Farmacia. Internado no Médico. Australia.

\section{INTRODUCTION}

Internationally, curriculum in universities is concerned in ensuring that graduates develop attributes which will better equip them for the world of work, and as members of society. ${ }^{1}$ In the context of the work presented in this paper, at the end of an Australian undergraduate degree, students should have gained an understanding of a systematic and coherent body of knowledge and its underlying leva STUPANS. PhD. Professor of Pharmacy. School of Science and Technology, University of New England. Armindale, NSW (Australia). 
principles and concepts as well as a number of core competencies. These competencies include communication and problem-solving skills; the ability to undertake research, analyse information and apply knowledge and techniques learnt within an academic or professional context; skills for selfdirected and lifelong learning; and interpersonal and teamwork skills appropriate to employment and/or further study. ${ }^{2}$

Health professionals in Australia, such as nurses, radiation therapists, pharmacists, physiotherapists and occupational therapists, currently undertake university programs comprising both theory and experiential components. Pharmacy programs in Australia may be four year undergraduate, bachelor's level, programs or two year graduate entry master's level programs. As compared to other allied health graduates, in Australia, pharmacy graduates are required to complete one year of preregistration training as a pharmacy intern before evidencing competence and applying for registration as a pharmacist as opposed to graduation and registration at the same time point. In relation to the pharmacy profession, the Competency Standards for Pharmacists in Australia ${ }^{3}$ define competencies as 'skills, attitudes and other attributes (including values and beliefs) attained by an individual based on knowledge (initially gained through tertiary education) and experience (gained through subsequent practice)'. Competencies are outlined within eight functional areas with specific elements, performance criteria and examples of the type of evidence to demonstrate competence. Core general abilities for a pharmacist include teamwork, critical thinking, ethics, communication skills and lifelong learning. Australian undergraduate pharmacy degrees are generally structured such that students learn science-based principles of pharmacy in the first 2-3 years of the degrees and clinical pharmacy skills are largely taught in the latter stages of the curriculum.

The international literature sheds little light on allied health professionals' experience of the transition from student to pharmacy employee ${ }^{4}$ and there is limited consensus about how to measure this objectively. ${ }^{5}$ With respect to entering the pharmacy profession, studies from the United Kingdom across a number of pharmacy schools have identified graduates' high levels of perceived preparedness for performance of pharmacists' tasks and for a professional approach to tasks. ${ }^{6}$ Reports from a New Zealand study, focussing on students' satisfaction regarding a new degree program also gathered data from intern preceptors. Preceptors commented that factors such as individual graduate's life skills and personalities would influence their adaptability to the workplace. ${ }^{7}$ In Australia little work has been reported from the students' or graduates' perspective regarding professional or workplace preparedness. One study conducted, with academics and preceptors, interrogating student' preparedness across all competency functional areas indicated variability across states and territories with respect to competency development in academic pharmacy programs. $^{8}$
Professionally accredited Australian university pharmacy programs equip graduates to enter the profession as interns, who after completing preregistration training may apply for registration; however ideally they also equip them to enter the world of working in pharmacy. There is a need to understand what students take with them into their first job as intern pharmacists and identify potential curriculum gaps in their pharmacy studies. To date, little evidence around whether university programs are effective in equipping pharmacy graduates in transitioning to the world of work has been published.

By contrast, the transition for a much larger group of health graduates, nurses, has been examined across a number of countries, although the literature on the experience in Australian hospitals is still limited. ${ }^{4}$ Issues for newly graduated nurses include discrepancies between what graduates understand about nursing from their education and their experiences in the 'real' world of healthcare service delivery, a lack of clinical knowledge and confidence in skill performance, relationships with colleagues and workload demands ${ }^{9}$ and reflect the importance of bridging undergraduate curriculum with escalating workplace expectations. ${ }^{10}$ Transition stress has also been identified in the intern medical year $^{11}$ and consequently a number of curriculum approaches such a framework to support learning in clinical attachments, building collegial relationships and authentic assessment identified. ${ }^{12}$ It is important to note that managing transitions is not unique to healthcare. There is extensive literature on different aspects of the university to profession transition including teaching ${ }^{13}$ and business degrees; in the latter case curriculum innovations such as "capstone units" have been introduced. ${ }^{14}$

The purpose of this manuscript is to assess whether from the perspective of new pharmacy professionals there are additional areas in the curriculum which need to be addressed in order to prepare graduates for the transition to full-time work in pharmacy. This study utilised interns' stories about their transition into the workplace to uncover aspects of both preparedness and unpreparedness.

\section{METHODS}

A series of one-on-one semi-structured interviews with intern pharmacists was undertaken with participants from one Australian state. The interns were recruited during intern training program workshops, in which approximately one hundred interns participated, through provision of written details of the project and invitation to participate in interviews. Participants were interviewed until no new information emerged, achieving saturation. Interns were undertaking internships in community pharmacies or hospital pharmacy departments. The interns had been engaged in their intern programs for approximately five months at the time of interview. The interviews were conducted by an independent, experienced interviewer who was not a pharmacy academic. Interviews involved encouraging the interns to provide a narrative of their transition experiences and describe the 
improvements they would like to see in the pharmacy program from which they had graduated. Questions were asked in response to interviewee narratives, probing additional detail. Notes of the discussion were taken by the interviewer. Notes were collated and analysed by the author of this paper through manual coding processes involving sorting; reading through information to make general sense; recording of thoughts about the data and organising material into categories. ${ }^{15}$ Ethics permission was obtained from the University of South Australia Human Ethics Committee

\section{RESULTS}

A total of 17 interns, who had all graduated from the one university were interviewed. Nine of the interviewees were working in community pharmacy, eight in hospitals.

The first point to note is the positive view of the undergraduate curriculum in preparing newly qualified pharmacists for practice; not one interviewee described the transition in terms related to "anxiety, insecurity, inadequacy and instability" as has been described for newly qualified nurses. ${ }^{10}$

There was no reference amongst the interviewees to a lack of theoretical pharmacy knowledge or of skills, however a number of interviewees referred to some aspects of their transition experiences which was for example 'getting into the working situation...working in a different environment' (intern 16, community). Through coding of the data from the interviews there was evidence of subthemes within the responses. These were those of relationships within the workplace and understanding differences between passing exams to satisfy degree requirements and the complexity of working, including adjusting to work hours. These responses are discussed in the themes below.

The first sub theme identified was that of learning about relationships within the workplace and the need to interest themselves in other people. The comments below capture this.

'...and the politics of any workplace..that's definitely a transition..You're much more guarded about how you conduct yourself' (intern 2, hospital)

'I'm learning how to interest myself in people...find a rapport with different people .. (intern 3, community)

'..You have to be considerate of other people..' (intern11, hospital)

'(at uni)...there's only so much you can tell people about what's an appropriate way to talk to people' (intern 8, hospital)

'...each week you meet new people...you have to small talk a lot.. You've got to show interest in people..'(intern 9, hospital)

The second subtheme was that of understanding differences between passing exams to satisfy degree requirements and the complexity of working, including adjusting to work hours. Comments included

'Uni never took up that much of my time.. ...(intern 3, community)

'bit of a shock ...adjusting to working hours...... did work part-time (25 hours) (at uni) ..but full time, that was a bit of a shock initially (intern 11, hospital)

'It's a big change from going to uni..you can go to lectures if you want... there's different expectations... You have to turn up to work, you can't make excuses...we have to go to work full time..... (intern 17, community)

'At uni .....at the end of the day, pass exams and pass tests to do what I had to do...(Work) you're expected to know more than things for a test, you're working towards a different goal...(difficult) to transition from a uni lifestyle into understanding the expectations of being an employee ...It's hard to prepare yourself for that transition...I was studying so I knew it for that day and that exam' (intern 2, hospital)

Given working a new environment i.e. a pharmacy work environment rather than the university, there were suggestions that the period of placement in the program be increased.

'What's most lacking in pharmacy compared to other health disciplines...only two one month placements is not enough... you need more placements. ...(intern 1, community)

Those 2 one month work experiences...that was good...it was a good way of exposing you to work fulltime...before I only worked three hours a night, not nine to five' (intern 17, community)

'If you hadn't had much exposure..if you hadn't had a job, it might be difficult...'(intern 5,hosp)

Aside from that other parts of the university program were referred to as having been important in preparing these graduates for practice. Role plays and case studies in the third and fourth year clinical pharmacy subjects were referred to by a number of students. Comments included

Professional practice good 'it involved a lot of role plays...gives case studies that put us in real situations.....helps us to see the common drug interactions and how to deal with the situation' (intern 2, community)

\section{DISCUSSION}

Prior to conducting this study the author had anticipated that new professionals would describe aspects of linking theoretical knowledge to practical application as challenging for them during their transition ${ }^{16,17}$ given the differences between universities and practice sites. ${ }^{18}$ The interview strategy for the work outlined in this paper enabled interviewees to describe these aspects if appropriate. 
No comments regarding specific professional knowledge, or skills were made. Instead issues of workplace relationships, adjusting to work hours and understanding differences between university assessments and performing in a workplace were identified. It can be hypothesised that for these interns, to that point of their internship there may have been only a limited requirement for application of theoretical knowledge in the practical pharmacy work setting. This may be a finding which is peculiar to Australian pharmacy practice or a finding which is peculiar to work as opposed to placements as part of a degree program. Studies in Australia have indicated that the linking of theoretical knowledge to activity in clinical pharmacy placements is viewed by students, academics and clinical placement preceptors as contributing to quality clinical placements. ${ }^{19}$ Additionally, there is evidence for this linkage in Australian clinical pharmacy placements. $^{19}$ Similarly, specifically in Finland, studies have indicated that many students felt they were able to link their theoretical knowledge to their activity in clinical pharmacy placements. ${ }^{20}$ The concept of only limited application of theoretical knowledge in the practical pharmacy work setting needs to be considered further in the light of current practice in Australia which is heavily based on drug distribution and in which practicing pharmacists have found the implementation of, for example, cognitive services to be challenging. ${ }^{21}$

There is potential for curriculum development in response to the notion of differences between assessment at university and in the workplace. Current mainstream educational thinking is dominated by a constructivist view, which argues that deep learning occurs when a learner is actively engaged in learning activities and occurs where previous learning is linked with current. ${ }^{22}$ Program wide assessment, rather than assessment of individual subjects, whereby there is assurance that graduates know and can apply the basics which can then be applied in the authentic context, potentially in process-based activity, and appropriate selfassessment activities may address some of these concerns. ${ }^{23-25}$

The comments made by some respondents regarding the benefits of having worked previously and around the clinical placement period are similar to those from New Zealand graduates ${ }^{7}$ who suggested that those who had worked part-time as students in community pharmacy were better prepared to undertake their internships and felt that that the placements arranged by the school were too brief.

Limitations of this study include the lack of generalisation as the interviewees were not representative of all interns across all graduates from pharmacy programs in Australia and instead from one university. There is a need to replicate the work reported in this paper with graduates of other universities. Disparity in findings may provide insight into curriculum measures which potentially reduce transition issues for graduates. Alternatively similar findings may provide insight into positive aspects of the pharmacy intern work environment.

Pharmacy graduates from this particular Australian university are prepared for the world of pharmacy work. The concept of "transition shock" or "transition stress" described for recent nursing graduates ${ }^{10}$ and medical interns ${ }^{11}$ respectively and for other professionals transitioning to the workplace was not apparent. There were no perceptible curriculum gaps regarding application of university knowledge to the 'real' world of practice.

\section{ACKNOWLEDGEMENTS}

Support for this work was provided by the Australian Learning and Teaching Council.

\section{CONFLICT OF INTEREST}

None declared.

\section{References}

1. Barnett R. Supercomplexity and the Curriculum. Studies in Higher Education, 2000;25(3):255-265.

2. Framework AQ. AQF Qualification by Sector of Accreditation. Available at: http://www.aqf.edu.au/Portals/0/Documents/Handbook/AQF_Handbook_51-72.pdf.

3. Competency Standards for Pharmacists in Australia. Pharmaceutical Society of Australia; 2010.

4. Smith RA, Pilling S. Allied health graduate program - supporting the transition from student to professional in an interdisciplinary program. J Interprof Care. 2007;21(3):265-276.

5. Moriarty J, Manthorpe J, Stevens M, Hussein S. Making the Transition: Comparing Research on Newly Qualified Social Workers with Other Professions. Br J Soc Work. 2011;41(7):1340-1356.

6. Willis SC, Hassell K, Seston EM, Hann M. Using learning outcomes for undergraduate pharmacy education to assess final-year students' perceptions of their preparedness for pharmacy practice. Int J Pharm Pract. 2009;17(6):351-358

7. Kairuz T, Case S, Shaw J. Perceptions of graduates and preceptors regarding a new pharmacy programme. Pharm Educ. 2007;7:151-157.

8. Owen S, Stupans I, Ryan. G, McKauge L, Woulfe J. Support needed by pharmacy students in experiential placements: stakeholders' expectations. J Pharm Pract Res. 2010;40(2):99-102.

9. Duchscher JB. A Process of Becoming: The Stages of New Nursing Graduate Professional Role Transition. J Contin Educ Nurs. 2008;39(10):441-450.

10. Duchscher JEB. Transition shock: the initial stage of role adaptation for newly graduated Registered Nurses. J Adv Nurs. 2009;65(5):1103-1113.

11. Katinka P, Margaretha Van de W, Cees Van der V, Henny B, Albert S. Junior Doctors Opinions about the Transition from Medical School to Clinical Practice: A Change of Environment. Educ Health (Abingdon). 2004;17(3):323-331. 
12. Tweed MJ, Bagg W, Child S, Wilkinson TJ, Weller JM. How the trainee intern (TI) year can ease the transition from undergraduate education to postgraduate practice. N Z Med J. 2010;123(1318):81-91.

13. Corcoran E. Transition Shock. Journal of Teacher Education 1981;32(3):19-23.

14. Bailey J, Oliver D, Townsend K. Transition to practitioner: Redesigning a third year course for undergraduate business students. Journal of Management \& Organization. 2007;13(1):65-80.

15. Strauss A, Corbin J. Basics of Qualitative Research: Techniques and Procedures for Developing Grounded Theory. Thousand Oaks, CA: Sage; 1998.

16. Eraut M. Developing Professional Knowledge and Competence. London:The Falmer Press; 1994.

17. Benner P, Tanner C, Chesla C. Expertise in Nursing Practice - Caring, Clinical Judgement and Ethics. New York: Springer Publishing; 1995.

18. Burke V, Jones I, Doherty M. Analysing student perceptions of transferable skills via undergraduate degree programmes. Active Learning in Higher Education, 2005;6(2):132-144.

19. Stupans I, McKauge L, Owen S. Indicators of a quality clinical placement in pharmacy: Stakeholder perspectives J Pharm Pract Res. 2011;41(2):118-121

20. Katajavuori N, Lindblom-Ylänne S, Hirvonen J. The Significance of Practical Training in Linking Theoretical Studies with Practice. Higher Education 2006;51(3):439-464.

21. Roberts AS, Benrimoj SI, Dunphy DC, Palmer IC. Community pharmacy: strategic change management. Sydney:McGraw-Hill; 2007.

22. Ramsden P. Teaching and Learning in Higher Education: London: Routledge;1992.

23. Boud D. Avoiding the traps: seeking good practice in the use of self assessment and reflection in professional courses. Soc Work Educ. 1999;18(2):121-132.

24. Eva KW, Regehr G. Self-Assessment in the Health Professions: A Reformulation and Research Agenda. Acad Med. 2005;80(10 Suppl):S46-S54.

25. Andrade $\mathrm{H}$, Valtcheva A. Promoting Learning and Achievement through Self-Assessment. Theory Into Practice. 2009;48(1):12-19. 